\title{
Feasibility study of a biocompatible pneumatic dispensing system using mouse 3T3-J2 fibroblasts
}

\author{
Sangmin Lee ${ }^{1 *+} \mathbb{D}$, Hojin $\mathrm{Kim}^{2+}$ and Joonwon Kim²
}

\begin{abstract}
This paper presents results for dispensing living cells using a pneumatic dispensing system to verify the feasibility of using this system to fabricate biomaterials. Living cells (i.e., mouse 3T3-J2 fibroblast) were dispensed with different dispensing pressures in order to evaluate the effect of dispensing process on cell viability and proliferation. Based on the results of a live-dead assay, more than $80 \%$ of cell viability has been confirmed which was reasonably similar to that in the control group. Furthermore, measurement of cell metabolic activity after dispensing confirmed that the dispensed cell proliferated at a rate comparable to that of the control group. These results demonstrate that the pneumatic dispensing system is a promising tool for fabrication of biomaterials.
\end{abstract}

Keywords: Pneumatic dispensing, Living cell, Viability, Proliferation

\section{Background}

Technologies to manipulate living cells are widely employed in biological and tissue engineering applications. For example, depositing living cells at a specific location is useful to help understand how cell behavior such as proliferation, differentiation, and migration is related to local environment (e.g., extracellular matrix and neighboring cells) [1-4]. Also, in tissue engineering, which seeks to repair injured or ill organs, it is necessary to seed living cells at a precise position in three-dimensional (3D) scaffolds to achieve successful production of artificial tissues or organs [5-7].

To construct 3D cellular structures, many cell patterning technologies have been developed, including micro-contact printing using soft-lithography [8], and microfluidic technology [9]. These technologies can produce a high resolution pattern, but they are inconvenient

\footnotetext{
*Correspondence: thinking@deu.ac.kr; joonwon@postech.ac.kr

${ }^{\dagger}$ Sangmin Lee and Hojin Kim contributed equally to this work

${ }^{1}$ Department of Mechanical, Automotive and Robot Component

Engineering, Dong-Eui University, 176 Eomgwang-ro, Busanjin-gu, Busan 47340, South Korea

${ }^{2}$ Department of Mechanical Engineering, Pohang University of Science and Technology (POSTECH), 77 Cheongam-ro, Nam-gu, Pohang, Gyeongbuk 37673, South Korea
}

to form 3D structures and expensive to change patterns [10].

Recently, dispensing (e.g., inkjet printing) technology has attracted much attention for use as a tool to fabricate structures consisting of various cell types [11-15]. Because the dispensing technology can make a precise cell pattern directly by dispensing small droplets of biological materials containing living cells, it has advantages of simplicity and flexibility for fabrication of complex cellular structures. The dispensing technology is flexible to pattern various designs by simply controlling the position to dispense living cells in droplets from a nozzle. Furthermore, because the dispensing technology can be easily integrated with computer-assisted manufacturing systems, it can use solid free-form fabrication to precisely form complex 3D cellular structures [16, 17]. Also, it can form cellular structures that consist of different cell types by using and controlling multiple nozzles, each with a corresponding reservoir [5].

For tissue engineering applications, considerable research has been devoted to extending the capability of dispensing technology to create artificial tissues or organs. Because living cells are easily damaged by heat and mechanical stress [5], the biocompatibility of the dispensing system must be assessed by evaluating the 
effect of the dispensing process on cell viability and proliferation. Living cells have been dispensed using various printing systems such as thermal inkjets [11], piezoelectric inkjets [12-15], electrostatics [5], lasers [18], and electrohydrodynamic jets [19].

This paper presents results for dispensing living cells using a pneumatic dispensing system to verify the feasibility of using it as a biocompatible fabrication tool. The pneumatic dispensing system uses a simple yet effective mechanism with a backflow stopper and a flexible membrane, so it is easy to control droplet volumes and to eject highly viscous liquid $[20,21]$. To assess the biocompatibility of the dispensing system, experiments were conducted using mouse 3T3-J2 fibroblast cells at various operation conditions, then cell viability and proliferation were evaluated using a live-dead assay and a cell counting kit assay, respectively.

\section{Materials and methods}

\section{Pneumatic cell dispensing system}

To dispense the liquid droplet containing living cells, an experimental setup using a pneumatic dispensing system was developed as shown in Fig. 1a. A cell suspension from a reservoir is delivered to the dispenser by applying a steady air pressure (i.e., inlet pressure) to the reservoir. Using a magnetic stirrer at the bottom of the reservoir, cells were prevented from sedimentation by gravity and uniform dispersion of cells was maintained.

The dispenser has the top (glass) and bottom (silicon) substrates separated by a flexible membrane made of a polydimethylsiloxane (PDMS) film as shown in Fig. 1b. A large through-hole connected to controlled pressures (positive and negative) was machined through the top substrate. The flexible membrane (thickness $\sim 70 \mu \mathrm{m}$ ) is deformed by the applied pressure. The bottom substrate including a liquid chamber, an inlet, and a sideway outlet (Table 1) was fabricated using conventional micromachining technology as described in our previous paper [20]. The reservoir and the dispenser were washed with $70 \%$ ethanol and then with phosphate-buffered saline (PBS) prior to use.

The flexible membrane is deflected by the applied pressure, and thus draws in or dispenses liquid. The membrane is either pulled (negative pressure) or pushed (positive pressure) depending on the programmed electric signal. The applied pressure is normally negative; a pulsed signal switches a solenoid valve to provide positive pressure (during duration time) to dispense the liquid. The liquid is drawn into the chamber when the membrane is pulled (during delay time) and dispensed when it is pushed.

\section{Preparation of cell suspension}

A cell suspension was prepared using mouse fibroblasts (3T3-J2 cells) obtained from the American Type Culture Collection (Manassas, VA). Cells were cultured in Dulbecco's modified Eagle's medium (DMEM, Gibco BRL, Gaithersburg, MD) supplemented with $10 \%$ bovine calf serum (Gibco), 1\% mixture of penicillin and streptomycin (Gibco). Cells were cultured at $37{ }^{\circ} \mathrm{C}$ in a humidified incubator in an atmosphere containing $10 \% \mathrm{CO}_{2}$ [22]. To apply living cells to the dispensing system, cells in culture flasks were trypsinized, then cell pellets were collected, and resuspended in a phosphate-buffered saline (PBS, Gibco) solution. The suspension contained 500,000 cells $\mathrm{mL}^{-1}$, as quantified using a hemocytometer.

\section{Cell viability assay}

The viability of dispensed cells as compared with a pipetted control was quantified using a LIVE-DEAD ${ }^{\circledR}$ assay Kit (Lonza, Walkersville, MD). Live cells fluoresce green unless the cell membrane is damaged in which case they fluoresce red. Before dispensing cells on a substrate (96-well plate), a collagen gel layer was formed on the substrate surface (Fig. 2a). Collagen is a well-known universal cell binder and is widely applied in cell culture [23]. A dilute $\left(1.25 \mathrm{mg} \mathrm{mL}^{-1}\right)$ aqueous solution of type-I rat tail collagen (BD Biosciences, Bedford, MA) was prepared using sterilized DI water, then diluted 9:1 (volume ratio) with $10 \times$ DMEMS (Gibco). A $40 \mu \mathrm{L}$ of the mixture was pipetted into each well on the plate, then incubated at $37^{\circ} \mathrm{C}$ for $30 \mathrm{~min}$ to form the collagen gel layer. After collagen gelation process, $30 \mu \mathrm{L}$ of a mixture of $2 \mu \mathrm{M}$ calcein $\mathrm{AM}$ and $4 \mu \mathrm{M}$ ethidium homodimer-1 solution from the live-dead kit was added to each well (Fig. 2b). Then a single liquid droplet (volume $\sim 250 \mathrm{~nL}$ ) containing cells was dispensed directly onto each well of the plate (Fig. 2c). At the same time, $1 \mu \mathrm{L}$ of the four times diluted cell suspension (i.e., 125,000 cells $\mathrm{mL}^{-1}$ ) was pipetted on the plate, as a control. Dispensed cells were incubated for $30 \mathrm{~min}$ at room temperature, then a fluorescence microscope (IX71 microscope, Olympus) was used to obtain images of stained cells.

\section{Cell proliferation assay}

To confirm the proliferation of dispensed cells, their metabolic activity was measured using a cell counting kit (CCK-8, Dojindo, Kumamoto, Japan). Twenty droplets of cell suspension (total volume $\sim 5 \mu \mathrm{L}$ ) were dispensed into each well of a 96-well plate supplemented with $100 \mu \mathrm{L}$ of fresh culture medium (Fig. 3a). After dispensing the cells, $10 \mu \mathrm{L}$ of CCK- 8 solution was added to each well and the plates were incubated for $2 \mathrm{~h}$ at $37^{\circ} \mathrm{C}$ in an atmosphere containing $10 \% \mathrm{CO}_{2}$ (Fig. 3b). The emitted fluorescence of samples at $450 \mathrm{~nm}$ was measured using a micro-plate 


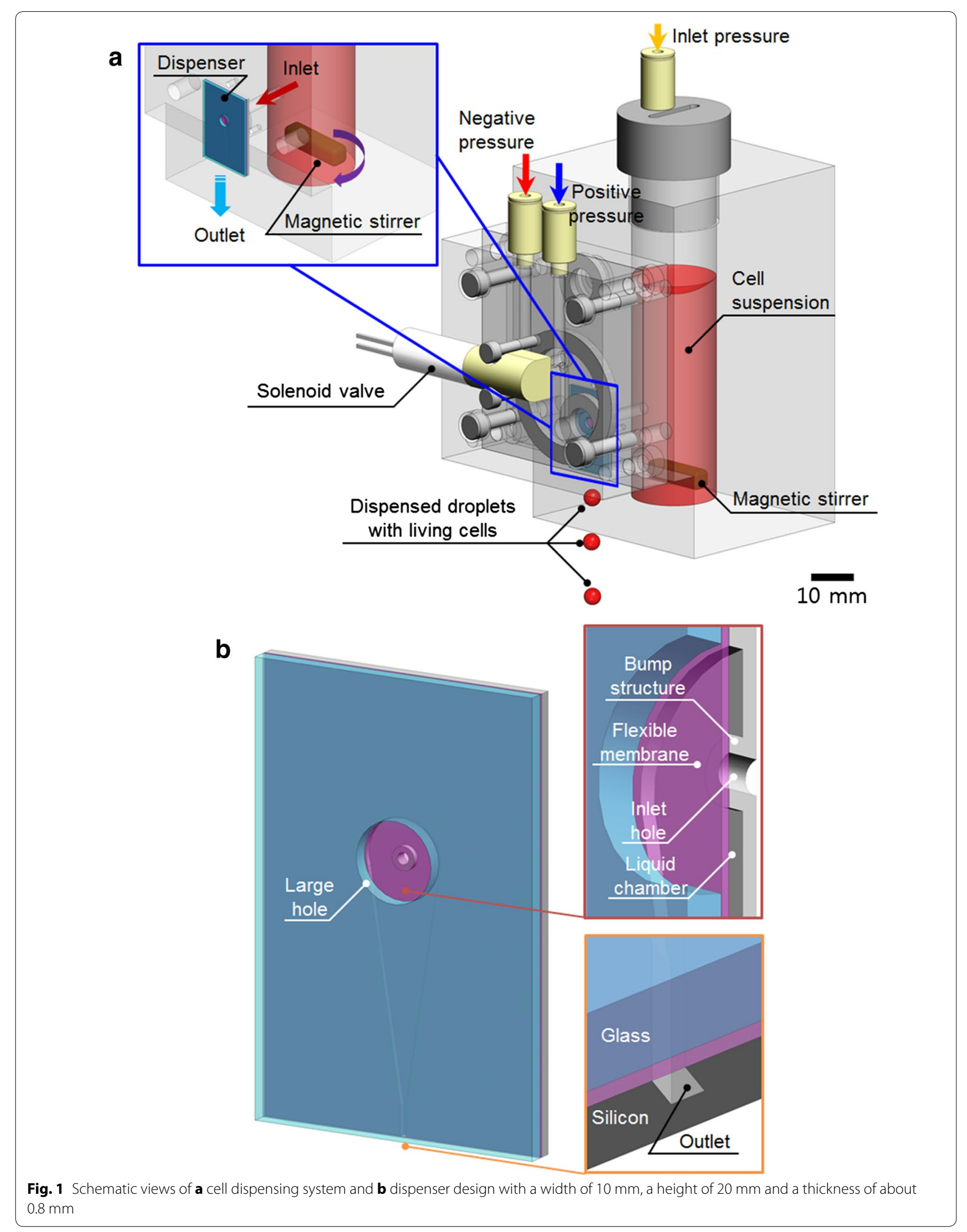


Table 1 Summary of design parameters

\begin{tabular}{lr}
\hline Design parameters & $\begin{array}{c}\text { Size } \\
(\boldsymbol{\mu m})\end{array}$ \\
\hline Chamber & \\
Diameter & 2000 \\
Height & 100 \\
Bump & \\
Diameter & 400 \\
Height & 80 \\
Inlet hole & \\
Diameter & 200 \\
Outlet nozzle & \\
Width & 100 \\
Height & 100 \\
\hline
\end{tabular}

reader (UVM 340, Biochrom, Cambridge, UK). Samples were measured repeatedly for continuous monitoring of the same sample at each time point $(4,24,48$, and $72 \mathrm{~h}$ ) after dispensing the cells. After the fluorescent was measured, wells including cells were washed with PBS solution and incubated in fresh culture media (Fig. 3c). The culture media were changed and the cells returned to the incubator. At the same time and well plate, $5 \mu \mathrm{L}$ of the same cell suspension was pipetted as a control.

\section{Results and discussion}

To test the biocompatibility of our dispensing system, cell viability and proliferation were analyzed qualitatively using live-dead and CCK- 8 assays. A statistical significance was determined using analysis of variance (ANOVA) on MINITAB version 14.2 (Minitab Inc., State College, PA, USA). A $P$ value less than 0.05 was considered statistically significant.

\section{Cell viability}

Damages to cell membranes by physical forces (i.e., shear stress) during dispensing process were observed in optical images using a live-dead assay. Cell suspension was dispensed at positive pressures from 25 to $100 \mathrm{kPa}$

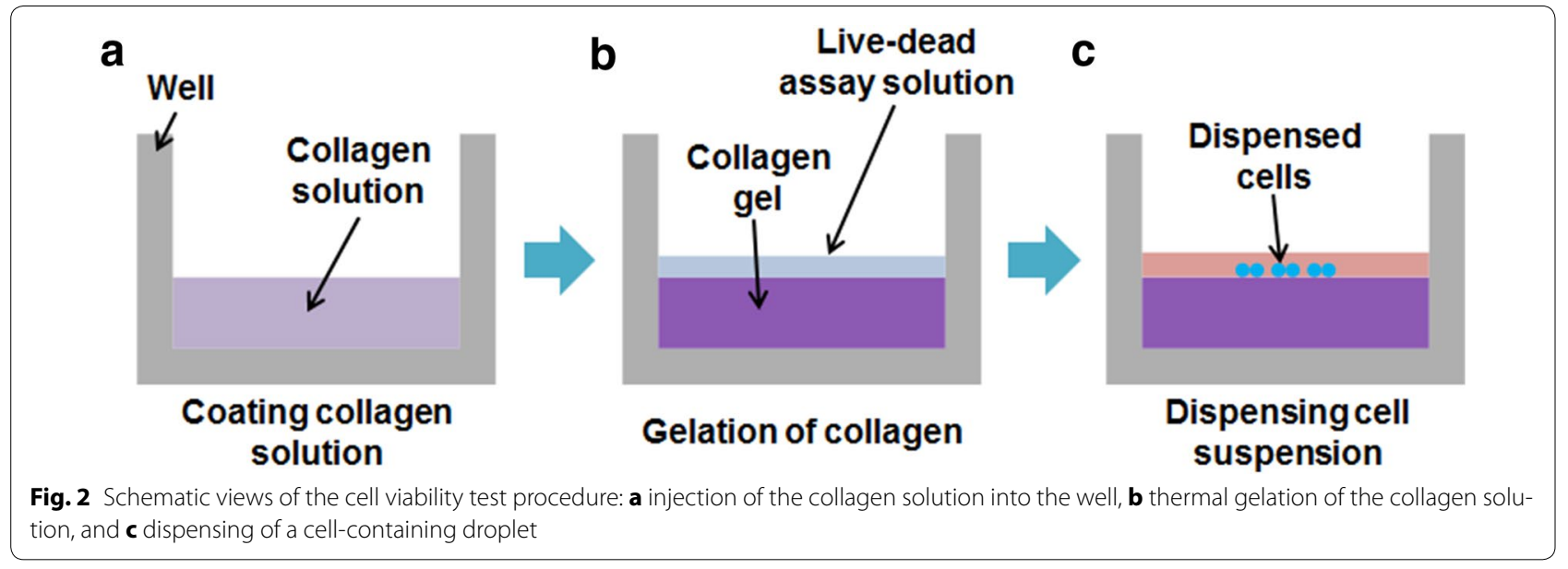

a

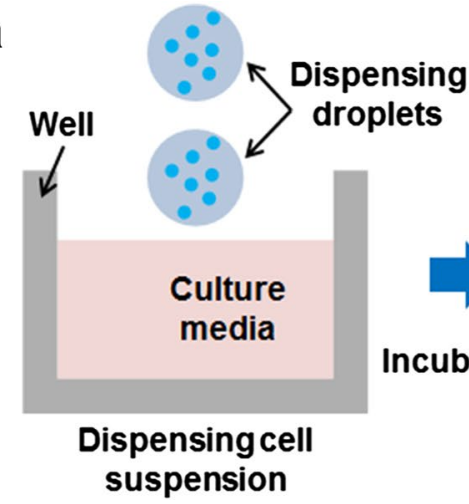

b

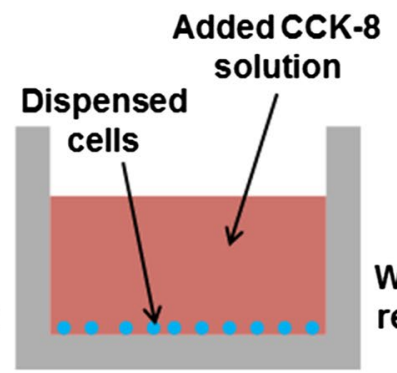

Measuring the optical density c

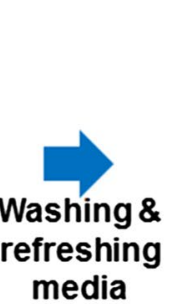
media

\section{Incubating in fresh media}

Fig. 3 Schematic views of the cell proliferation test procedure: $\mathbf{a}$ dispensing of cell droplets into the well, $\mathbf{b}$ addition of the CCK-8 solution into the well and measurement of light absorbance after incubation, and c replacement with fresh cell media 
while the droplet volume was varied from 182 to $274 \mathrm{~nL}$ $(\mathrm{CV}<1.2 \%)$. Images of stained cells which were almost all of cells containing a single droplet (90-130 cells per droplet) were shown in Fig. 4. The cell viability was calculated by counting live or dead cells for each image at each dispensing pressure $(n=8)$. The mean cell viability and standard deviation (SD) were plotted in Fig. 5. The viability of dispensed cells ranged from 81 to $83 \%$ for applied pressure values $(25-100 \mathrm{kPa})$, and was not affected significantly by applied pressure $(P>0.05)$. The average viability of dispensed cells was slightly less than that of the control group ( 94\%). This difference in viability may have occurred because the higher droplet velocity subjected dispensed cells to a larger shear stress than those experienced by cells in the pipetted control. For the current design of the dispenser, the measured droplet velocities were in range from 1.6 to $5.4 \mathrm{~m} / \mathrm{s}$ while applied pressures were changed [24], which are higher than typical inkjet printing system such as piezoelectric or thermal bubble jet [25].

\section{Cell proliferation}

Even if a cell membrane is not damaged, its function may be impaired by the stress experienced during the dispensing process [11]. So cell metabolic activity after dispensing was measured using a CCK- 8 assay. Measurements were made starting at $4 \mathrm{~h}$ after dispensing, which is needed for the cells to settle and adhere to the substrate, then repeated daily for up to 3 days $(72 \mathrm{~h})$. Under the same operating conditions, 20 droplets were

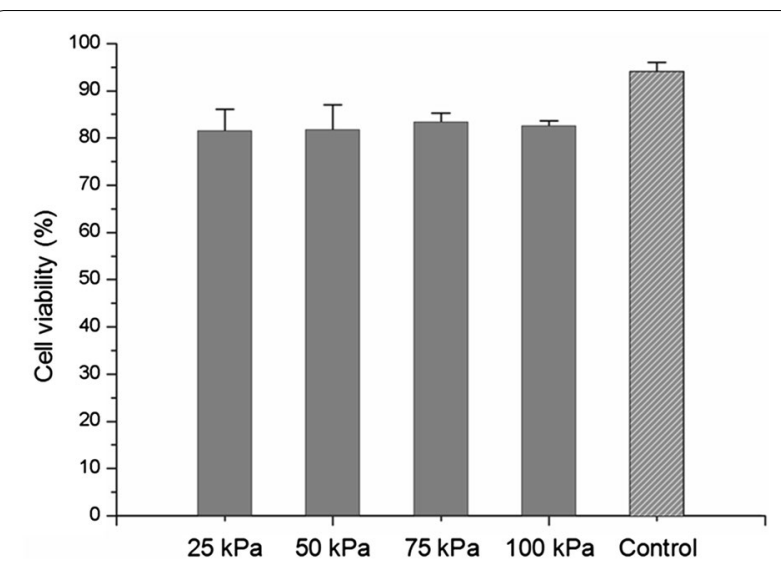

Fig. 5 Cell viability result for various positive pressures. The graph shows a slight loss of cell viability after cell dispensing

dispensed repeatedly into each well with the control $(\mathrm{n}=5)$. All samples were dispensed in one sequence over no more than $10 \mathrm{~min}$ using a single batch of cells in suspension. Figure 6 shows the mean value of optical density (OD) at $450 \mathrm{~nm}$ and SD for each time interval. The measured OD values of all samples show a progressive increase over time $(P<0.05)$. These results suggest that the cells were proliferating at a rate comparable to that of the control.

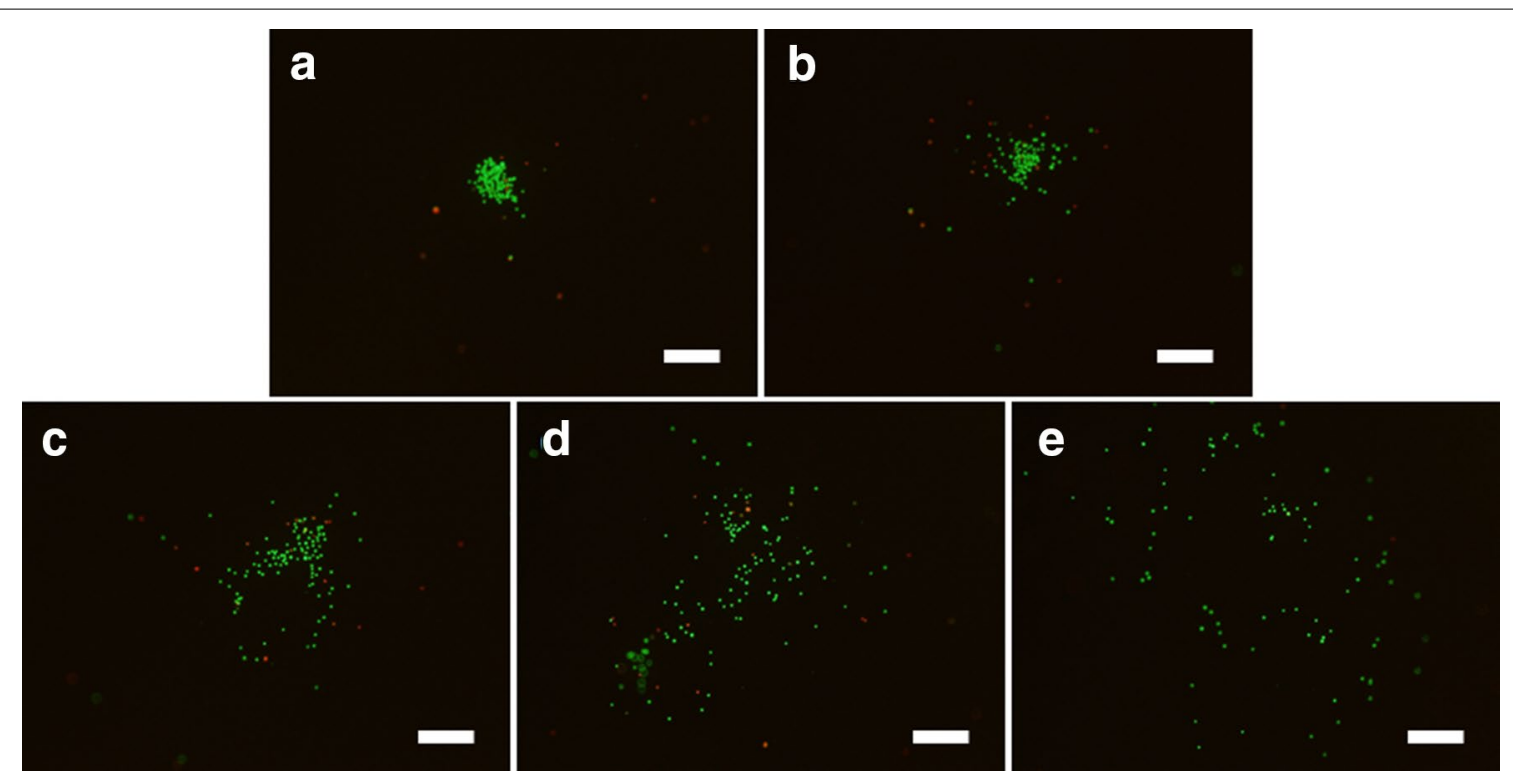

Fig. 4 Live-dead assay of fibroblast cells dispensed onto a collagen gel at positive pressures of a $25 \mathrm{kPa}, \mathbf{b} 50 \mathrm{kPa}, \mathbf{c} 75 \mathrm{kPa}$, d $100 \mathrm{kPa}$, and e the control (pipetting). All scale bars are $500 \mu \mathrm{m}$ 


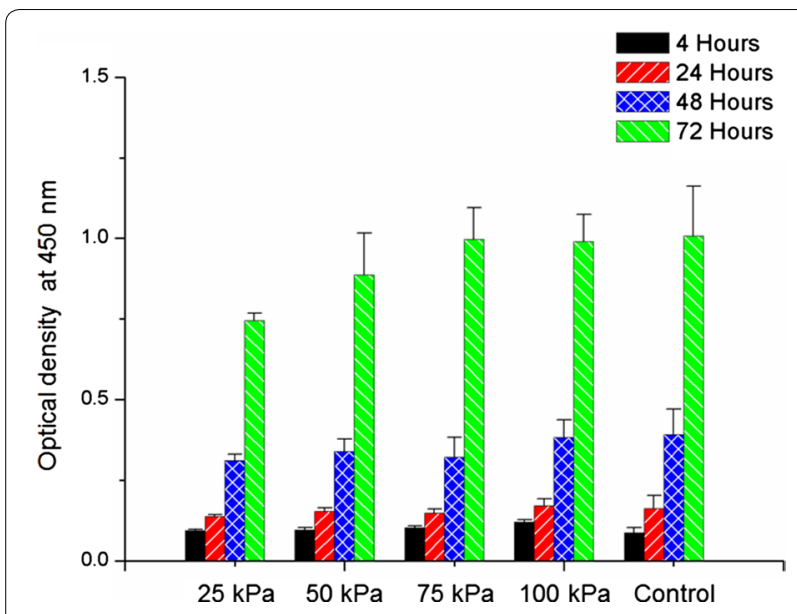

Fig. 6 Cell proliferation result as a function of time in culture after dispensing at different positive pressures. The graph demonstrates that the cell proliferation rate is similar for various positive pressures $(P<0.05)$

\section{Conclusion}

The effect of our dispensing system on cell viability and proliferation was assessed at various applied pressures. Based on the results of a live-dead assay, more than $80 \%$ of cell viability has been confirmed which is reasonably compatible to the control group. Cell metabolic activity measurements confirmed that the dispensed cells were proliferating at a rate comparable to that of the control. These results confirm the feasibility of using our pneumatic dispensing system to dispense living cells for fabrication of biomaterials.

\section{Authors' contributions}

$\mathrm{LS}$ and $\mathrm{KH}$ performed the experiments, analyzed the data and wrote the manuscript. All authors read and approved the final manuscript.

\section{Competing interests}

The authors declare that they have no competing interests.

\section{Availability of data and materials}

The datasets supporting the conclusions of this article are included within the article and its additional files.

\section{Ethics approval and consent to participate}

Not applicable.

\section{Funding}

This work was supported by Dong-eui University (Grant No. 201702730001) and the National Research Foundation of Korea (NRF) Grant funded by the Korea government (MSIT) (Nos. 2017R1C1B1008045 and 2017R1C1B5076710).

\section{Publisher's Note}

Springer Nature remains neutral with regard to jurisdictional claims in published maps and institutional affiliations.

Received: 25 September 2017 Accepted: 20 November 2017

Published online: 24 November 2017

\section{References}

1. Devillard R, Pagès E, Correa MM, Kériquel V, Rémy M, Kalisky J, Ali M, Guillotin B, Guillemot F (2014) Cell Patterning by laser-assisted bioprinting. Methods Cell Biol 119:159-174. https://doi.org/10.1016/ B978-0-12-416742-1.00009-3

2. Shi M, Ling K, Yong KW, Li Y, Feng S, Zhang X, Pingguan-Murphy B, Lu TJ, Xu F (2015) High-throughput non-contact vitrification of cell-laden droplets based on cell printing. Sci Rep 5:17928. https://doi.org/10.1038/ srep17928

3. Xu T, Gregory CA, Molnar P, Cui X, Jalota S, Bhaduri SB, Boland T (2006) Viability and electrophysiology of neural cell structures generated by the inkjet printing method. Biomaterials 27:3580-3588

4. Miller ED, Fisher GW, Weiss LE, Walker LM, Campbell PG (2006) Dosedependent cell growth in response to concentration modulated patterns of FGF-2 printed on fibrin. Biomaterials 27:2213-2221

5. Nakamura M, Kobayashi A, Takagi F, Watanabe A, Hiruma Y, Ohuchi K, Iwasaki Y, Horie M, Morita I, Takatani S (2005) Biocompatible inkjet printing technique for designed seeding of individual living cells. Tissue Eng 11:1658-1666

6. Nakamura M, Iwanaga S, Henmi C, Arai K, Nishiyama Y (2010) Biomatrices and biomaterials for future developments of bioprinting and biofabrication. Biofabrication 2:014110. https://doi. org/10.1088/1758-5082/2/1/014110

7. Matsusaki M, Sakaue K, Kadowaki K, Akashi M (2013) Three-dimensional human tissue chips fabricated by rapid and automatic inkjet cell printing. Adv Healthc Mater 2:534-539

8. Tanaka N, Ota H, Fukumori K, Miyake J, Yamato M, Okano T (2014) Micropatterned cell-sheets fabricated with stamping-force-controlled microcontact printing. Biomaterials 35(37):9802-9810

9. Collins DJ, Morahan B, Garcia-Bustos J, Doerig C, Plebanski M, Neild A (2015) Two-dimensional single-cell patterning with one cell per well driven by surface acoustic waves. Nat Commun 6:8686. https://doi. org/10.1038/ncomms9686

10. Goubko CA, Cao X (2009) Patterning multiple cell types in co-cultures: a review. Mater Sci Eng, C 29:1855-1868

11. Xu T, Jin J, Gregory C, Hickman JJ, Boland T (2005) Inkjet printing of viable mammalian cells. Biomaterials 26:93-99

12. Lorber B, Hsiao W-K, Hutchings IM, Martin KR (2013) Adult rat retinal ganglion cells and glia can be printed by piezoelectric inkjet printing. Biofabrication 6(1):015001. https://doi.org/10.1088/1758-5082/6/1/015001

13. Zhang J, Chen F, He Z, Ma Y, Uchiyama K, Lin J-M (2016) A novel approach for precisely controlled multiple cell patterning in microfluidic chips by inkjet printing and the detection of drug metabolism and diffusion. Analyst 141:2940. https://doi.org/10.1039/c6an00395h

14. Xu T, Zhao W, Zhu J-M, Albanna MZ, Yoo JJ, Atala A (2013) Complex heterogeneous tissue constructs containing multiple cell types prepared by inkjet printing technology. Biomaterials 34:130-139

15. Kim YK, Park JA, Yoon WH, Kim J, Jung S (2016) Drop-on-demand inkjetbased cell printing with 30- $\mu$ m nozzle diameter for cell-level accuracy. Biomicrofluidics 10:064110

16. Kim JY, Yoon JJ, Park EK, Kim DS, Kim S-Y, Cho D-W (2009) Cell adhesion and proliferation evaluation of SFF-based biodegradable scaffolds fabricated using a multi-head deposition system. Biofabrication 1(1):015002

17. Mironov V, Boland T, Trusk T, Forgacs G, Markwald RR (2003) Organ printing: computer-aided jet-based 3D tissue engineering. Trends Biotechnol 21(4):157-161

18. Xiong R, Christensen K, Fu J, Markwald RR, Huang Y (2016) Freeform laser and inkjet printing of biological constructs. 2016 International symposium on flexible automation, Cleveland, Ohio, USA, 1-3 August 2016

19. Liaudanskaya V, Gasperini L, Maniglio D, Motta A, Migliaresi C (2015) Assessing the impact of electrohydrodynamic jetting on encapsulated cell viability, proliferation, and ability to self-assemble in threedimensional structures. Tissue Eng Part C 21(6):631-638. https://doi. org/10.1089/ten.tec.2014.0228

20. Lee S, Kim J (2010) Development and characterization of a cartridge-type pneumatic dispenser with an integrated backflow stopper. J Micromech Microeng 20(1):015011. https://doi.org/10.1088/0960-1317/20/1/015011

21. In Ho Choi and Joonwon Kim (2016) A pneumatically driven inkjet printing system for highly viscous microdroplet formation. Micro Nano Syst Lett 4:4. https://doi.org/10.1186/s40486-016-0030-x 
22. Park J, Berthiaume F, Toner M, Yarmush ML, Tilles AW (2005) Microfabricated grooved substructures as platforms for bioartificial liver reactors. Biotechnol Bioeng 90:632-644

23. Liberski AR, Zhang R, Bradley M (2009) In situ nanoliter-scale polymer fabrication for flexible cell patterning. JALA 14:285-293

24. Lee S, Choi IH, Kim YK, Kim J (2014) Velocity control of nanoliter droplets using a pneumatic dispensing system. Micro Nano Syst Lett 2:5. https:// doi.org/10.1186/s40486-014-0005-8
25. Saunders RE, Gough JE, Derby B (2008) Delivery of human fibroblast cells by piezoelectric drop-on-demand inkjet printing. Biomaterials 29:193-203

\section{Submit your manuscript to a SpringerOpen ${ }^{\odot}$} journal and benefit from:

- Convenient online submission

- Rigorous peer review

- Open access: articles freely available online

- High visibility within the field

- Retaining the copyright to your article

Submit your next manuscript at $\boldsymbol{\nabla}$ springeropen.com 